\title{
Prospects for the Realization of Human Rights: Rural Nigeria in Perspective
}

\author{
Matthew Adefi Olong ${ }^{1}$ \\ ${ }^{1}$ Senior Lecturer and Head of Department, Commercial \& Industrial Law, Kogi State University Anyigba, \\ Nigeria \\ Correspondence: Matthew Adefi Olong, Senior Lecturer and Head of Department, Commercial \& Industrial Law, \\ Kogi State University Anyigba, Nigeria. Tel: 23-480-3406-9932. E-mail: adefiolong@yahoo.com
}

Received: January 21, 2011

Accepted: February 10, 2012 Online Published: May 11, 2012

doi:10.5539/jpl.v5n2p40

URL: http://dx.doi.org/10.5539/jpl.v5n2p40

\begin{abstract}
The article examines the fact that the realization and enjoyment of human rights in the rural majority in Nigeria has remained a myth. The urban dwellers may have had some measure of the enjoyment of the rights. But same cannot be said of the rural majority. The article reiterates that most civilized of states therefore is not one which has constitutionally provided for these rights perse but one which has adequate machinery and constitutional safeguards for the protection, enforcement and enjoyment or realization of these rights. In this wise, the article suggests ways of realizing these rights in rural Nigeria.
\end{abstract}

Keywords: prospects, realization, human rights, rural nigeria, perspective

\section{Introduction}

The relevance of human rights among families, societies, nations and institutions of the world in the third millennium cannot be overestimated. These remains so because, these rights are inherent in man and inalienable in character, which are recognized by governments as such and constitutionally entrenched and guaranteed to the citizens of the given State. Human rights is important to man as life itself, and is this millennium, it has become not only a buzzword but the yardstick for measuring an organized, civilized or democratic society, determined essentially by reference to the quality of their constitutional guarantee, and the machineries provided for their protection, enforcement and enjoyment. The most civilized of states therefore is not one which has constitutionally provided for these rights per se, but one which has adequate machinery and constitutional safeguards for the protection, enforcement and enjoyment or realization of these rights.

The urban dwellers may have had some measure of the enjoyment of these rights. But could same be said of the rural majority? The writer seeks to x-ray the prospects for the realization of enjoyment of human rights in the rural areas of Nigeria. In line therefore, a synoptic appraisal of the origin of human rights in Nigeria will be ventured into and a retrospective look at the practice and enjoyment of human rights in rural Nigeria with a view to analyzing the prospects for the realization of human rights in rural Nigeria. The writer concludes by spotlighting the observations made in the course of the work and making concomitant recommendations for the better enjoyment or realization of human rights in rural Nigeria.

\section{Conceptual Clarifications}

\subsection{Human Rights}

A precise definition of human rights has been as Herculean a task as having a 'Carmel pass through the eye of a needle'. In other words, the concept of human rights eludes precise definition. The term has however been defined by Nachi (1996:157) as constitutionally guaranteed rights of the citizen. This definition is however bereft of substance, as it does not tell what human rights is all about. Osita Eze (1984:5) sees human rights as claims which individuals or groups make on society, some of which are protected by law and have become part of the lex lata whilst, others remain aspirations to be attained in future. Akin to this definition is that by Ukhuegbe (1991:22) who sees human rights as claims by individuals and groups against the community or the State, which are recognized as essential to human nature or personality.

It is therefore, clear that the term human rights elude precise definition as the boundaries of human rights cannot be precisely determined. What is clear however is the fact that these rights are claims by the individual against 
the State which have been constitutionally guaranteed, though some of the claims are merely entrenched in the constitution without any measure of guarantee as to their enjoyment.

Under the Nigerian Constitution, there are claims which are fundamentally guaranteed as rights to be enjoyed by the citizens which are remediable upon breach. These set of rights are called civil or political rights. There is however other claims which are not guaranteed in the Constitution either as guiding principles of state policy or as privileges which may, upon progressive development become rights in themselves in the future. These set of rights are non-justiceable and thus cannot be remedied in the Courts upon breach. These set of claims are regarded as social and economic rights. It is noteworthy to stress that the non-justiceability of social and economic rights does not in any way diminish the quality and character of these claims as necessary compliments for the due enjoyment or realization of the civil and political rights. In the words of Nnamdi Aduba (1992:220), human rights and social justice should be complementary of each other. Having one in the absence of the other makes little or no sense.

Human rights in Nigerian Constitutional history may be traced back to the recommendations of the Willink Commission on Minorities which was set up by the Government following widespread allegations of discrimination against the minorities and other violations of their human rights. The recommendations of this Commission were entrenched in the Constitution of 1958, and have been progressively developed and retained in the Independence and subsequent post Independent Constitutions. Under the present Constitution of the Federal Republic of Nigeria, elaborate provisions on human rights is provided for in chapter 4 thereof, the contents of which is modeled on the United Nations' 'Universal Declaration on Human Rights' 1948, and the 'European Convention for the Protection of Human Rights and Fundamental Freedoms, 1950.

By the 1999 Constitutional arrangement, the following fundamental freedoms are provided for in chapter 4 thereof: Right to life, Right to Dignity of human person ,Right to Liberty, Right to Fair Hearing, Right to Private and Family life, Right to Freedom of Thought, Conscience and Religion ,Right to Freedom of Expression and the Press, Right to Peaceful Assembly and Association, Right to Freedom of Movement, Right to Freedom from Discrimination, Right to Acquire and Own Immovable Property anywhere in Nigeria ,Right against Compulsory Acquisition of Immovable Property.

Although there are elaborate provisions in the respective constitutions of Nigeria, the problems have not been with the entrenchment of these provisions but rather with the practice and enjoyment of these rights. As was once remarked by Obaseki (1992:248) that experience has shown in many cases that the real question is not whether fundamental rights are asserted on paper, but whether they are recognized in practice and can be secured

\subsection{Rural Nigeria}

A definition of the term rural Nigeria can only be appreciated in the light of the definition proffered by Aduba (2003:1) as that part of Nigeria which is characterized by the following: Lack of pipe-borne water or water from the bore-holes; abundance of guinea-warm infested water; absence of electricity, lack of accessible roads, or means of communication; absence of educational institutions at where they are exist the distance between the institutions and the inhabitants are such that only very determined could take advantage of; lack of basic health facilities; absence of courts of law' absence of lawyers about $80 \%$ persons of Nigerians reside here, the major economic activity is subsistence farming, poverty is the order of the day, the standard of living is very low. Up till date, no definition of rural Nigeria has bettered that of Aduba; the Pictorial leverage remains very clear and precise. Rural Nigeria is the chequered rendezvous of which Franz Fawn aptly referred to as the "wretched of the earth". There is no doubt that rural Nigeria is the repository of human beast of burden, the bastion of those who toil night and day to eek a living; those who yearn moment by moment for the improvement of their lot through development of some sort. The majoritarian workforce without whom there may never be any bread, basket for Nigeria as Akubo (2008:169) remarked but regrettably, they are ignored in their squalor. Their daily and year in year out cry for fertilizer amounts to nothing.

Rural Nigeria could be likened to that part of Nigeria that is easily tantalized and susceptible to the sweet promises of venal time-servers in their political gimmicks. Rural Nigeria is a harrowing woe of a failed state.

\subsection{Culture}

According to Granner (2009:) culture is said to be the result of cultivation: a type of civilization whilst custom on the other hand has been defined as a usage or practice of the people which by common adoption and acquiescence and by long and unvarying habit has become compulsory and has acquired the force of a law with respect to the place or subject matter to which it relates. 
Customary or cultural practices are therefore rules of conduct established by usage or continuous practice over a long time. Osborne C.J. in Lewis v Bankole (1969:1NLR, 100) had this to say about customary law that:

One of the most striking features of West African native custom... is its flexibility; it appears to have been always subject to motives of expediency and it shows unquestionable adaptability to altered circumstances without entirely losing its character.

Thus custom is dynamic and not static. It is subject to change particularly over a long period of time. There exist such customary practices in different parts of rural Nigeria, some of which have evolved into customary law, and are enforced as such by the existing authorities/ruling bodies. Some of these practices have been written down as laws, but most of them are largely unwritten but have the force of law. They are accepted by the communities concerned and are applies in some cases ruthlessly. Some of then do not even pass the repugnancy test, and as such are contrary to known principles of natural justice.

\section{Practice and Enjoyment of Human Rights in Rural Nigeria}

The Nigerian experience as to the enjoyment of fundamental human rights as guaranteed in the Constitution has been rather sour and has been marked with recurrent flagrant abuses by not only the executive and the Legislature but also, and sadly too, by the judiciary. This situation is worse in the rural areas of Nigeria where there is high-level prevalence of illiteracy and poverty - a situation aggravated by unbridled corruption.

There is also epidemic of Police brutality and unconstitutional detentions. As if that is not enough the rural populace suffer human rights abuses from traditional institutions and harmful cultural practices common to the community, such as trial by ordeal, widowhood practices, genital mutilation (circumcision), child marriages, child labour, as well as withdrawal, and the awareness level is very low, the victims rarely seek redress or resolutions to their problems in the Court of Law. And where they are prepared to go to Court, the appropriate Courts are rarely available as the courts in the rural areas are most Area Courts or at best Magistrate or District Courts which are not Courts of record.

Where appropriate Courts are available, the doors of justice are shut against the victims by the high cost of fees and the high level of corruption in the Judiciary. This accounts for the dearth materials regarding human rights abuses in the rural areas of Nigeria. It becomes appropriate to view practices that impede enjoyment of Human Rights in rural Nigeria such as:

\subsection{Death by Witchcraft, Trial by Ordeal}

One of the most fundamental of all rights and privileges conferred on and enjoyed by man is the right to life. Human life is regarded as sacred and dignified by God. This sanctity of human life therefore prohibits man from taking the life of another. This right is fundamentally guaranteed under the Nigerian Constitution which provides to the effect that every person has a right to life and no one shall be deprived intentionally of his life, save in execution of the sentence of a Court in respect of a criminal offence of which he has been found guilty in Nigeria. By this provision deprivation of life is prohibited unless in execution of a sentence of Court of competent jurisdiction upon a conviction for crime. Other exceptions are provided under the provision by which one may kill in the reasonable exercise of defence of self or property, or to effect lawful arrest or to prevent the escape of a detainee or arrestee, or further still, to suppress a riot, insurrection or mutiny.

It is sad to observe that though there are constitutional safeguards to the right to life, many lives are unlawfully taken especially in the rural areas of Nigeria through witchcraft practices, juju (charms), trials by ordeal or even by extra-judicial killings by the police. All these constitute a grave violation of the right to life and need be urgently checked to avert further violations or abuse.

\subsection{General Mutilation a.k.a. Circumcision}

Genital mutilation which is an age-old customary practice in many areas of the world involves the surgical operation or cutting of the foreskin of the genital or sexual organ of the person. This practice dates back to the Abrahamic period of biblical history, by which God entered into a covenant with Abraham and his posterity for ever, which covenant was sealed and symbolized in the circumcision of all male children after eight days of birth While the covenant with Abraham was for the circumcision of male children, the practice in most parts of the world have transcended this boundary to include female children - a practice not intended or contemplated by the Abrahamic covenant. Njelesani (1997:27-28) opines that worse still, female circumcision have never been carried on early in the life of the girl -child; they are usually carried out when the girl might have reached the age of puberty, or on marriage, or on her first pregnancy. What is worst, the circumcision is often carried on by quack or native doctors who have no experience of surgery and without administering any form of anesthetics. This crude process usually leaves the lady bleeding profusely for long a time which may eventually occasion 
death, or some kind of virtual or bacterial infection. This is most indignifying and manifestly offends the provisions of the Constitution, and thus should not be allowed to continue whatever the justification for such practices might be. Every girl-child as indeed every woman and every individual is entitled to a right to respect for the dignity or her person, and any customary practice which violates this constitutional guarantee should be declared void; as the practice debases the individual and leaves her not only with physical but also with long-lasting psychological and emotional trauma. Infact her consent need be first sought and obtained, before any circumcision may be carried on her.

\subsection{Child Marriage}

By the provisions of the Children and Young Persons Act, a child is a person of or under the age of 14 years. Child - marriage therefore is a marriage by or with a person of 14 years of age or less, or marriage with a person who has not attained majority. Marriage, by its very nature is a contract between the parties or couples thereto. Olong (2006:45) posited that being a contract with legal incidences, the parties must be possessed of contractual capacity, i.e. must be of full age and capacity, and must enter into it without any element of compulsion, i.e. voluntarily upon mutual consent of the parties.

According to Ogar (2004:7) the practice in most communities, especially in the rural areas of Nigeria by which children are shamelessly force out in marriage leaves much to be desired. First, the children are not of marriageable age, and although most native laws and customs provide for the age of marriage, this is either not followed or the prescribed age falls short of civilized standards.

Again, it is not voluntary as the consent of the child is not sought and obtained before being given out in marriage. This practice has been described by Aduba (2002:191-194) as "marriage by capture." The jurisprudence of the matter requires that irrespective of the good intention of the parents, the consent of the child should be first sought and obtained, to cloth such marriage with legal validity. Failing this, the practice of child marriage amount to a grave violation of the child's right to respect for the dignity of her person, and of her personal liberty as guaranteed under the constitution and should accordingly he stopped as inconsistent therewith.

\subsection{Widowhood Practices}

One of the greatest affronts to the realization of Fundamental Human Rights especially in the rural areas of Nigeria is the widowhood practices which are common to most communities, and which have, sad to note, become institutionalized in these communities. To start with, the practices are discriminatory, oppressive and dehumanizing. In its discriminatory outlook, whilst the death of customary law marriage automatically bring inheritance. The woman is not a chattel neither is she the husband's property nor should not by any wisdom become an object of inheritance. Aduba (2002:191) argued that upon the death of the husband, the widow is subjected to oppressive and dehumanizing treatment that leaves her psychologically, emotionally (and sometimes physically) traumatized. She is made to account for the entire husband's property, nothing of which may be given to her, irrespective of her needs. In some cases the widow is subjected to a trial by ordeal to prove that she was not responsible for the husband's death (this may take the form of merely taking an oath, or sleeping with the corpse, or worst still, made to drink of the water used to bath the corpse. Aside the foregoing, and as if not enough, the widow would be made to wear or mourning veil (usually black clothes) for a considerable length to time, shave her hair and sit on sackcloth throughout the mourning period, and to provide a list of items, including a goat or chicken for rituals.

Although these practices across all communities of Nigeria with varying degrees of application and severity, these practices are today being whittled down considerably by the influence of Christianity, modernity and education. However, much still needs to be done in order to completely eliminate these practices from our societies, as they constitute a grave violation of the fundamental rights of the widows to respect for the dignity of human person and to their liberty.

\subsection{Property Rights/Inheritance}

Akin to the foregoing in magnitude and severity of application is the issue of property rights of women generally and married women in particular. Most customary practices do not recognize the woman as having proprietary rights, i.e. a woman cannot and should not own property. Married woman are regarded as "property" of their husbands, and like slaves, whatever they own are those of their husbands, and no more. According to Abraham (1940:117) though she is entitled to the consortium of the husband and is to be carried catered for by the latter and may farm on his land, her "right, however is not proprietary for she evidently cannot hold or dispose of any part of the property. She is expressly precluded from holding or disposing of property, as indeed any other free 
citizen. This manifestly offends the woman's right to personal liberty and to acquire and hold immoveable property as guaranteed in the Constitution. It is the view of Justice Omololu Thomas in Adewole 7 Ors $v$. Jakande \& Ors (Unreported:S/N.M120/80 of 22/08/1980, that the right to personal liberty is not restricted to movement alone, but also includes freedom of contact, private enterprise and right to property. But the practice in most rural communities is for from this as the woman's right over, not only the husband's property, but also hers is only possessory and not proprietary. This agrees with the finding of Justice Chukwudifu Oputa in Uzodike (1999:305) to the effect that a woman cannot own land in her own right in many village communities.

This is manifestly inconceivable in an age in which women are becoming more and more responsible, and are actually the bread winners of many a family. If the woman has successfully broken the historical trend in which the man is regarded as the sole bread winner of the family, and has taken bold steps in assuming responsibilities in the society, there is no justification depriving her of the right to own, manage and dispose of property, which are essential ingredients in the running of the family or the society.

In the area of succession and inheritance women are not allowed in most communities to share in the estate of their deceased parents or husbands. The respective native laws and customs of most communities do not permit the woman or widow to take part in the deceased's estate. This practice has persisted for a long time. In Nezianya v Okagbue (1929:9NLR, 79), the Court reaffirmed the customary status quo by holding that a widow has only a possessory and no proprietary right over land of the deceased husband. This certainly is unjust and contrary to all known principles of natural justice, equity and good conscience. For it is inequitable and manifestly unjust to deprive a woman of the property she labored with the husband to acquire or even of her own property (landed or otherwise) acquired through her personal efforts. Such customary practices should be declared by the Court as null and void as inconsistent not only with natural justice, but, and importantly too, with the Constitution.

Thanks to judicial activism and civilization, the practices are gradually being phased out from Nigeria. Recently, the Court, in Mojekwu v Mojekwu (1997:7NWLR,PT512,283) condemned such practices as inconsistent with equity and fair-play in an egalitarian society which does not discriminate against women; holding further that all human beings male, female are born into a free world and are expected to participate freely without any inhibition on grounds of sex. Any form of societal discrimination on grounds of sex apart from being unconstitutional is antithesis to society built on the tenets of democracy and is repugnant to natural justice, equity and good conscience.

It is hoped that this radical departure from the status quo would be courageously sustained, thereby eliminating the clogs in the enjoyment of human right especially by the rural women.

\subsection{Poverty}

The word poverty eludes precise definition. However, the term has been defined by the Blacks Law Dictionary as the state or condition of being poor. Chief Obafemi Awolowo (1981:76) once defined poverty as the condition which exists when a person lacks the means to satisfy the 'necessaries' of life. 'Necessaries' has been defined to mean those things without which an individual cannot reasonably exist. Accordingly, poverty imports a condition of inability to provide oneself with the bare necessities of life which includes food, clothing, shelter, education, medication, and the like, Nigerian people, despite the enviable natural endowments of the land ironically live in the conditions of poverty, manifested by starvation, illiteracy, lack of shelter, clothing, health services and those bare necessities of life, and indeed in circumstances unworthy of the dignity conferred on man by God which has been recognized and entrenched in our constitution.

This situation fundamentally, puts a clog in the enjoyment of the fundamental right of the people as guaranteed, and this makes no sense to them when one stoops to discuss issues of human rights. Dr. Akinola Aguda (1988:1) aptly captured the situation when he asserted that the practical actualization of most of the fundamental rights cannot be achieved in a country like ours where millions are living below starvation level. In the circumstances of this nature fundamental rights provisions enshrined in the Constitution are nothing but meaningless jargon to all of our people living below or just at starvation level.

The present writer agrees intoto with the views expressed by the learned jurist. For of what use is it to talk about human right to a person who has no hope of a meal for himself or his family. There is the African proverb that says, "the belly carries the head" in other words, it is what is in the belly that carries what is in the head. A hungry man cannot therefore be reasonably expected to sit down to conceptualize or discuss anything meaningful about human rights. 
Unfortunately, in Nigeria as in most African countries, poverty is perpetuated by the elites though the manipulation of the people and government policies. For instance is it imaginable that government would make comprehensive policies on education, poverty reduction/eradication, socio-economic development, etc in the Constitution, but refuse to make such provisions justiceable. Without socio-economic rights, to what extent can fundamental human rights be meaningful to the average citizen, and of what value can those rights actually be? According to Prof. Uchegbu (1981:153) the right to life presupposes as a minimum the right to food, shelter, health and education. This is in agreement with the views of Prof Aduba (2002:7) that one sure way to get out of this menace of poverty is for African leaders and the Constitutions of African States to courageously prosecute policies aimed at the development of the human person. For if the human person is developed and economically empowered, the society would be developed and poverty eradicated thereby; but a situation in which African leaders spend a greater percent of national budgets on celebrations and the building of super structure at the expense of the development of the human person, his economic empowerment and the provision of social services and infrastructure facilities leaves much to be desired, as the attendant effect hope that the initiative of the African leaders as embodied in the New partnership for Africa's Development (NEPAD) which has as one of its aims the eradication of poverty in Africa and to place the countries of Africa on the path of sustainable growth and development would be vigorously pursued and implemented for the common good of the peoples of Africa. But if African leaders are sincere to themselves and the people, they have nothing to lose from making socio-economic rights justiceable as necessary compliments to the guaranteed fundamental rights. For indeed, as noted by Bronwen Manby (2003:103) a right-based approach also provides a legal basis for advocacy to ensure that the basic needs of the poor are met, and identified legal mechanisms for public service accountability.

\subsection{Illiteracy}

Illiteracy and poverty are like two sides of the same coin. It imports a condition of inability to read or write in the conventional or any language at all, or a condition of being unlearned or unlettered, or not attaining any form or level of education. Education is a universal right provided for under the Universal Declaration of Human Rights.

Although education is a universal right, this is far from reality in Nigeria, as in most African countries. Rather than a right education is provided for under the Constitution merely as an objective or directive principle of state policy, and although the wordings of the provision are fascinating, it is, like any other item under the chapter made non-justiceable. Section 18 of the Constitution provides for the educational objective of the government to the effect that:

1) Government shall direct its policy towards ensuring that there are equal and adequate educational opportunities at all levels.

2) Government shall strive to eradicate illiteracy, and to this end government shall as and when practicable provide -

a) Free, compulsory and Universal Primary Education

b) Free Secondary Education;

c) Free University Education; and

d) Free Adult Literacy Programme.

The provision on educational policy is wonderful but the implementation is, at best, a disappointment. This accounts for the very high level of illiteracy in Nigeria. The position has not changed after the enthronement of democratic rule in Nigeria in 1999. According to Dr. Ojo (1985:169) Nigeria is not safe under such a high illiteracy-level situation. In his own words: democracy is not safe in a country where a large majority of the population is illiterate.

The present writer agrees with the foregoing postulation of Dr. Ojo, for there can be no meaningful development of the country in the wake of such prevailing high-level illiteracy, and of which the government only pay lip-service.

Right from Independence to date, educational sector has suffered under-funding from successive regimes. Ironically, Federal Government budgets since Independence has been ridiculously highest in favour of Defence and at the expense of the Education and the Judiciary. This accounts for the incessant strikes at the different levels of our educational sector. Schools are not funded, salaries not paid, teaching/basic infra and superstructures are not maintained, thus leaving the whole system in decay. The situation is worse in the rural areas of Nigeria. 
Education is the bedrock for the advancement and enjoyment of all the rights and privileges accorded to man, and for the development of the entire society. The failure of education therefore means the advancement of illiteracy, which spells doom for any society. Government cannot mortgage the future of our country to illiteracy and economic doom by the deliberate refusal to sufficiently fund education. It is the call of the present writers that Government at all levels should consciously and sufficiently fund education for the better enjoyment of human rights, and for human societal development.

\subsection{Lack of Basic Social Amenities}

The enjoyment of fundamental human rights by rural dwellers of Nigeria is most affected by the lack of provision of basic social infrastructures such as access roads, portable water, health care services, electricity, schools, and etcetera.

Most rural communities have to access roads and in some cases motor vehicles only go there once in a week as a result of very bad roads. Within the communities, there is no portable drinking water, and the people are forced to drink from open rivers from where they usually bath and wash, and which water are often infected by guinea worm and other bacteria. Health Care Services are simply absent and rural dwellers have to resort to uncertified traditional or herbal medication, or travel for days in order to get to a Primary Health Care Centre, which, as is customary, are without drugs. As if that is not enough, rural dwellers have no access to electricity and are always in darkness, nor can they develop themselves along any small-scale business venture as a result of the absence of electricity - thus they are submerged in perpetual poverty. Their schools, most of which were built by the early missionaries have at best become dilapidated with no buildings or teaching/learning aids. The plight of rural dwellers must therefore be timeously looked into in order to enhance their human dignity, and if human rights is to make any meaning to them. One sure way of doing this is to make socio-economic rights justiceable.

\subsection{Access to Court/Legal Aid}

Access to Court is indeed a right of all the citizenry, and as fundamental as any of the other substantive rights guaranteed in the Constitution. The Constitution guarantees access to the court for the redress of the breach of any of the Fundamental rights as guaranteed. In this wise, Section 46 provides:

(1) Any person who alleges that any of the provisions of this chapter has been is being or likely to the contravened in any State in relation to him may apply to a High Court in that State for redress.

By the express wordings of the provisions, any person whose constitutional right has been, is being or is likely to be contravened has access to the High Court for redress. According to Professor Nwabueze (1982:320) the enforcement provision puts it beyond doubt that the mere likelihood of contravention of a guaranteed right confers a right of access to the Court. This is in line with the United States Supreme Court judgment in Adler $v$ Board of Education (1952:342U.S.485) where the enforcement was even more speculative than likely. It is also worthy of note that this provision which is in pari material with the provision in the 1979 Constitution is an improvement on the 1963 Republican Constitution in which the right was not extended to "likely" situations.

The problem is not with the provision but with the implementation, and the ease with which the Court could be accessed. The Constitution confers jurisdiction to entertain matters of human rights violation on the High Court of the State where the violation took place. whilst this is commendable, the High Court being a 'Court of record', it is however worrisome how this Court could be accessed by the rural populace, as the number of High Court in the State are very few and far from the rural communities, who may have to travel long distances in order to access the Court.

But access to Court means much more than locating the Court. The Court is a Court of record and there has to be filing of processes and other documents. All these requires money, and that costly too. In the end access to Court is largely limited or inhibited by the high cost of process fees as well as the Lawyer's fees, with the underling result that the door of justice is shut against the rural poor and the justice of the case 'sold' to the rich bidder.

The Constitution provides for the provision of Legal Aid to the indigent citizens, either in the form of financial assistance or assignment of a Counsel. But, how can these facilities which are mostly available in the cities be made available or accessible to the rural poor who are the ones actually in need of these facilities? According to Justice Oputa (1989:67-68) access to the Court is a necessary adjunct of the rules of law and the effectuation of his rights by the citizens. It underlines and emphasizes that justice should not be the privilege of the few who are rich but should be available to all the citizens of Nigeria. The efficacy of the Fundamental Rights provisions of the Constitution should therefore be whether the rights enshrined therein are accorded to the poor, the unemployed, the weak, the oppressed and the defenseless. 


\section{Conclusion and Recommendations}

It is observed that the enjoyment of human rights as guaranteed in the Constitution is either absent or at best minimal, especially in the rural communities of Nigeria that accounts for over $80 \%$ of the nation's population. Hopes cannot be lost if the following recommendations, are adhered to. The rural populace being in dire needs of basic infrastructures, such as pipe-borne water, electricity, access roads and health services. Governments at all levels should make the provision of basic social amenities a priority in their respective budgets. These are necessary if the dignity of the human persons of the rural dwellers is to be recognized, appreciated and enjoyed.

Accordingly, it is further recommended that educational institutions that are in dilapidated conditions, especially in the rural areas of Nigeria should be revived and facilities including teaching/learning aids provided. This would go in no small way in curbing the devastating menace of illiteracy in Nigeria.

Poverty is another bane to the enjoyment of Human Rights. Government should deliberately formulate, and execute policies and programmes aimed at eradicating poverty from the society. All known customary practices, such as female genital mutilation, child marriage, widowhood practices, discrimination against women, whether in the form of property right or education should be abolished or declared null and void as being inconsistent with known principles of Natural Justice, Equity and Good Conscience; and with the Constitution.

Fundamental Human Rights provisions are quite elaborate but the security for their enjoyment is far from expectation or reality. As necessary safeguard the socio-economic rights be made fundamental rights, and accordingly be made justiceable as necessary complements to civil and political rights.

Human Rights Commission should be made more meaningful to Government Areas as to be able to check human rights abuses, and High Courts being the Court for the determination of human rights violations should be established in all the Local Government Areas of the country and indeed in all major communities of Nigeria, as a necessary means for the realization of human rights, especially, in rural Nigeria.

Moreover, Judges and indeed the judiciary should be more pro-active and courageous in determining human rights cases brought before them as the Legal Aid should also be made more beneficial to the people by locating the office at least in all the Local Government Areas of Nigeria. Police excesses should be closely checked to prevent human rights abuses through unlawful deprivation of rights or the abuse of these rights though battering, unlawful detention and bribery. Anti Corruption Commission Offices to be set at the Local Government Areas to which human rights related corrupt practices may be reported; as to check the excesses of the Judges, Prosecutors and the police; and for the enhancement of the right to fair hearing. It would be well in the rural Nigeria if these recommendations are consciously implemented, thereby enhancing the enjoyment of human rights, in marginalized rural dwellers of Nigeria, rural Nigeria notwithstanding still share and remain part of Nigeria though neglected.

\section{References}

Abraham C. (1940). The Tiv People, $2^{\text {nd }}$ ed., (Herford, England: Stephen Austin \& Sons)

Adewole , Ors. V. Jakunde \& Ors. (Unrep.) S/N. M/120/80 of 22/08/1980.

Aduba, J. N (2002). "Some Customary Practices that affect the enjoyment of Fundamental Human Rights of Women in Nigeria”, in Dakas C.J. Dakas (ed)(2002) New Vistas in Law, 2. (Jos: St. Stephen Bookhouse Inc., 2002)

Aduba, J. Nnamdi (1992). 'Human Rights and Social Justice in Nigeria: Issues, Dilemmas and Options' in Awa U. Kalu \& Yemi Osibanjo (ed.) Perspectives on Human Rights (Ministry of Justice Law Review Series, 1992)

Aguda, A. (1988). "Judicial Process \& Stability in the Third Republic" (Cf. National Concord Newspaper, November, $7^{\text {Tt. }}$

Akubo P. A (2008). Prospects in the Realization of Fundamental Human Rights in Rural Nigeria, In suliman, A(2008) Corpus of Topical Legal Issues; Collection of Legal Essays Justice of Hon. Justice S.U. Onu (Kaduna, Legent Publishers Ltd, 2008)

Awolowo, O (1981). Path to Nigerian Greatness (Enugu: Fourth Dimension Publishing Co. Ltd)

Black, H.C (1991). Black's Law Dictionary, (6 ${ }^{\text {th }}$ ed), (St. Paul, Minn.: West Group)

Bronwen Manby (2003). "NEPAD and Human Rights” in Obadare, E. \& Oyewole Dapo (Ed): The New Partnership for Africa's Development: Challenges \& Development (Lagos: Centre for Democracy \& Development) 
Chapple v. Cooper (1844). 13 M \& W, 253, 258; per Alderson, B

Eze, Osita (1984). Human Rights in Africa (Ibadan: Macmillan Publishers Ltd)

Gasoiokwu, M.O.U. (2003). Human Rights: History, Ideology \& Law (Jos: FAB Educational Books)

Hyde v.Hyde (1886). L.R.I.P \&D, 130, 133

Nchi S.I. (1996). The Nigerian Law Dictionary ( $1^{\text {st }}$ ed) (Zaria: Tamaza Publishing Co. Ltd)

Njelesani, E.K (1997). “Female Genital Mutilation: An Avoidable Risk” in 'Images of the Nigerian Woman’, 2.

Nzekwe v.Nzekwe (1989). 3 SCNJ 167.

Nzewi,. Esther. (1989). 'Widowhood practices: A female perspective', in Proceedings of the Better Life Programme for Rural Women Workshop, Owerri)

Obaseki, A.O. (1992). “The Judiciary and Human Rights” in Awa U. Kalu \&Yemi Osibanjo (ed.) Perspectives on Human Rights (Federal Ministry of Justice Law Review Series, Vol. 12, 1992), 248.

Ogar Eneji ,Olong M.A. Fr. Allahmagami E. of blessed memory, Otuwokpo f, Ahmed A, Ibrahim P., \& Averemi O. (2004). "Prospects for the Realization of Human Rights in Rural Nigeria" being an unpublished LLM paper presentation Unijos, January.

Ojo, J. D. (1985). Development of the Executive under the Nigerian Constitution, 1960-1981 (Lagos: University Press)

Olong M. (2006). The Nigerian Child And Human Rights in the Third Millennium Ife Juris Review. Publication of Dept. of Private Law and Jurisprudence.

Oputa, Justice C. (1989). "Human Rights in the Political \& Legal Culture of Nigeria”: Idigbe Memorial Lectures (Lagos, Nigerian Law Publications Ltd.)

Peters v. Fleming (1840). $6 \mathrm{M} \& \mathrm{~W} 42$.

Uchegbu, P A. (1981). “The Concept of Right to Life under the Nigerian Constitution”, in Omotola, J. (1981). (Ed) Essays in Honour of Justice T.O. Elis, (Lagos: University Press)

Ukhegbe, S.O. (1991). Human Rights and Social Justice in Nigeria Issues, Dilemmas and Options.Conference paper presented at the Law Teacher's Conference held at Bayero University, Kano) 